\title{
The generative relationship between job quality, innovation, and employment
}

\author{
Chris Mathieu \\ Susanne Boethius
}

\section{Abstract}

Recent research on the interrelationships between innovation, job quality and employment shows a strong association between job quality and product, process, and to a lesser extent organisational innovation. Increased employment and improved job quality are found to result from innovation, while specific employment dimensions are found to impact innovation and job quality. This article presents in summary form the conceptual approach and central empirical results and conclusions of the Horizon 2020 project QulnnE (Quality of Jobs and Innovation Generated Employment Outcomes), a project that specifically targeted these interrelations for analysis. The findings, based on qualitative and quantitative studies, largely support the skill-biased technical change (SBTC) thesis, leading to the conclusion that while innovation tends to improve job quality, it will exacerbate societal inequalities. Evidence is also presented from several QulnnE studies that higher innovation results from higher job quality, in line with previous research. Relationships were not found to operate in a deterministic manner, but rather the actions of management, workers and social partners play important mediating roles in determining effects.

Keywords: Job quality, innovation, employment, QulnnE, inequality

\section{Introduction}

The European Union's concern with increasing and improving employment, social inclusion, innovation, and competitiveness were core to the Europe 2020 Strategy (European Commission 2010). There is an accepted wisdom that innovation is essential to competitiveness and growth (Mazzucato \& Perez, 2015), a fear that innovation may have detrimental effects on employment (Brynjolfsson \& McAfee, 2011; Frey \& Osborne, 2017), and not much understanding of (or interest in?) the connection between innovation and job quality (Duhautois et al., 2020). The latter is puzzling as aspects of job quality such as training and skill development are also a flagship initiative in the Europe 2020 Strategy. But no explicit connection between the two flagship initiatives in the Europe 2020 Strategy: the Innovation 
Union and the Agenda for new skills and jobs, nor innovation and job quality per se, is made. Furthermore, job quality is a core aspect of another key concern of the EU, sustainable work, especially in face of an ageing population in the EU. However, in the first round of funding of the research programme linked to the Europe 2020 Strategy, Horizon 2020, the project QulnnE - Quality of Jobs and Innovation Generated Employment Outcomes (grant number 649497) received funding to investigate the recursive and generative relationship between innovation, job quality and employment.

The purpose of this paper is to present in summary form the conceptual approach and central empirical results and conclusions of the QulnnE project, on the relationships between innovation, employment and job quality. Three things are highlighted. First, that QulnnE's empirical studies generally find consistent association between product, process and, to a lesser extent, organisational innovation and job quality. The reason for tenuous results for organisational innovation is likely due to the breadth of the concept as defined in the Oslo Manual's (2005) definition, which is used as the basis for OECD and Eurostat (most significantly the Community Innovation Survey) survey items on innovation. The second is that the studies generally find that innovation improves job quality and that innovative firms tend to increase, rather than decrease employment, even when implementing process and organisational innovations. As there is an increase in high-skilled jobs, and marginal or a negative impact on the number of low-skilled jobs, inequalities between the high and lowskilled are exacerbated, not mitigated by innovation. The third is that managerial, and sometimes employee agency plays an important role in the ways in which innovations are developed, selected, implemented and adapted, which have ensuing effects on job quality and employment. The article concludes by discussing policy implications of the findings.

\section{QulnnE's conceptual framework}

Figure 1 presents QulnnE's schematic representation and analytical "exploratory map" of the linkages between innovation and job quality, and the impact of those linkages on employment outcomes. As the project name and the bi-directional arrow between Innovation and Job Quality in the figure below indicate, a generative and recursive relationship entailing both cause and effect in the interaction between these fields is posited, with an interest in the employment effects of this relationship. Interest in employment outcomes comprised both the volume of jobs: the number of jobs created, destroyed or unaffected as measured in total number increases or decreases (i.e., More Jobs); as well as the quality of the jobs created, remaining or destroyed (i.e., Better Jobs). The interest in employment outcomes is directly linked to social inclusion (via labour market participation) and inequality (via skewed distribution of high- and low-quality jobs, and their inhering advantages and detriments to different groups). 

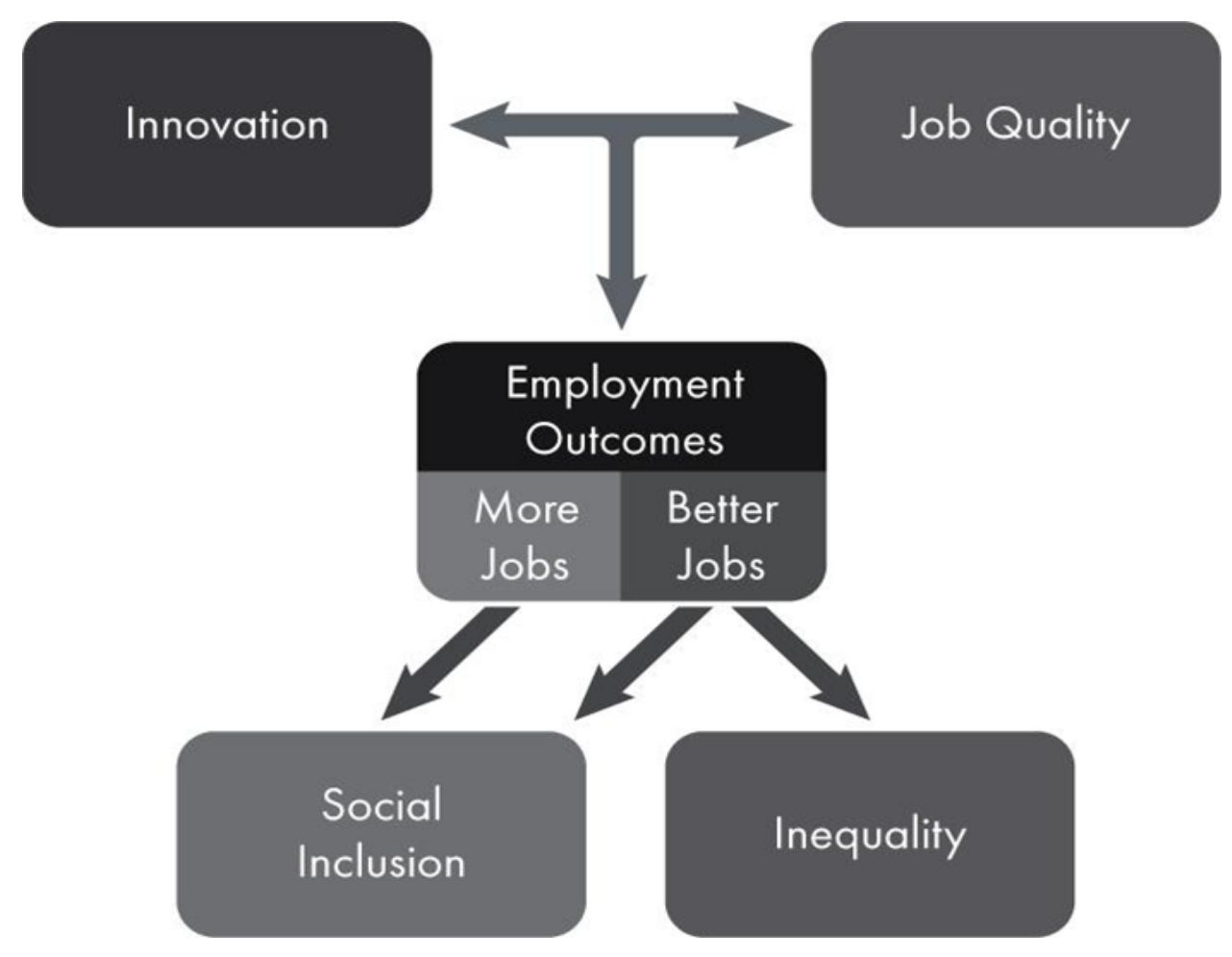

Figure 1: Schematic representation of QulnnE's conceptual framework

\section{Innovation}

The QuInnE project used the standardised terminology and definitions found in the $3^{\text {rd }}$ edition of the OECD/Eurostat's Oslo Manual (2005) ${ }^{1}$. These definitions are also embedded in the OECD and Eurostat's surveys from the period. In the $3^{\text {rd }}$ edition four types of innovation are delineated: product, process, organisational, and marketing innovations. The first two (product and process) are grouped as technological innovations, and the latter two (marketing and organisational) as non-technological innovations. This categorisation and definition of the types of innovation are shown in Figure 2. As QulnnE focused on work processes, marketing innovations were omitted from most of the studies.

\footnotetext{
1 The QulnnE project was carried out prior to the $4^{\text {th }}$ revision of the Oslo Manual in 2018, and therefore used the then-current and field-wide standardised terminology and definitions found in the $3^{\text {rd }}$ edition of the OECD/Eurostat's Oslo Manual (2005).
} 


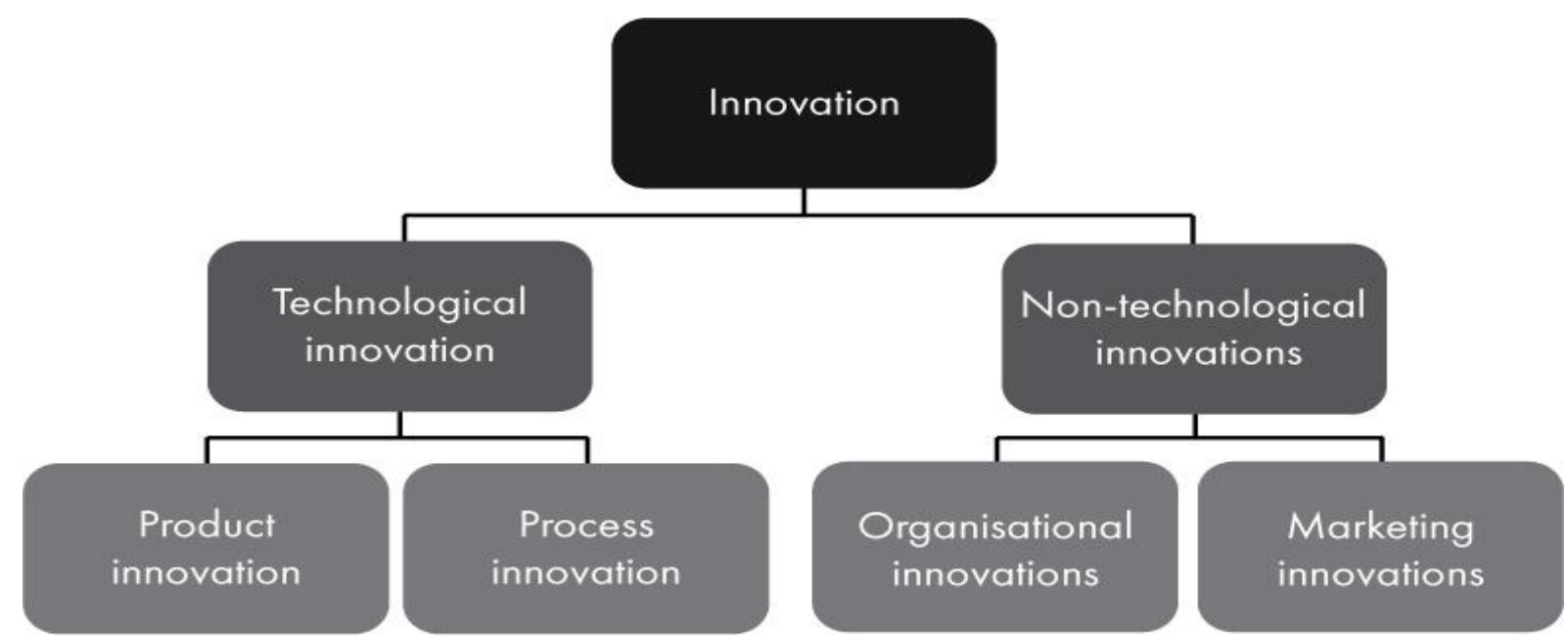

Figure 2: Types of innovation.

Product innovation: The introduction of a good or service that is new or significantly improved with respect to its characteristics or intended uses. Process innovation: The implementation of a new or significantly improved production or delivery method. This definition includes significant changes in techniques, equipment and/or software. Marketing innovation: The implementation of a new marketing method involving significant changes in product design or packaging, product placement, product promotion or pricing. Organisational innovation: The implementation of a new organisational method in the firm's business practices, workplace organisation or external relations. Source: Oslo Manual (OECD/Eurostat, 2005).

\section{Job quality}

In terms of job quality, QulnnE developed a multi-dimensional and cross-disciplinary approach comprising six main categories: wages, employment quality, education and training, working conditions, work life balance, and employee participation. These dimensions and their sub-dimensional indicators are presented in Table 1 below. This approach to job quality focuses on the broad range of intrinsic, extrinsic, physical, social, and material dimensions tied directly to work and employment.

Table 1: QulnnE's bespoke approach to job quality

\begin{tabular}{|l|l|}
\hline Dimension & Indicators \\
\hline \multirow{5}{*}{ Wages } & $\begin{array}{l}\text { Pay level relative to national minimum pay and average for required } \\
\text { qualifications }\end{array}$ \\
\cline { 2 - 3 } & Pay variability \\
\hline \multirow{5}{*}{ Employment Quality } & Permanent/Temporary Status \\
\cline { 2 - 2 } & Job Security \\
\cline { 2 - 2 } & Internal Progression Opportunities \\
\cline { 2 - 2 } & Predictability of Weekly Hours (Overtime - Zero Hours) \\
\cline { 2 - 2 } Education \& & Presence/Absence Involuntary Long Hour Work (40 +) \\
\cline { 2 - 2 } & Presence/Absence Involuntary Part-Time Work (<30) \\
\hline \multirow{5}{*}{ Training } & Learning Opportunities on the Job \\
\cline { 2 - 2 } & Training Incidence \\
\cline { 2 - 2 } & Training Quality \\
\cline { 2 - 2 } & Opportunities for General vs Specific Skill Acquisition (Transferability) \\
\hline
\end{tabular}




\begin{tabular}{|l|l|}
\hline \multirow{4}{*}{ Working Conditions } & Individual Task Discretion/ Autonomy \\
\cline { 2 - 2 } & Semi-Autonomous Teamwork \\
\cline { 2 - 2 } & Job Variety \\
\cline { 2 - 2 } & Work Intensity \\
\cline { 2 - 2 } Work Life Balance & Health and Safety (Physical and Psychosocial) \\
\cline { 2 - 2 } & Supervisory Social Support \\
\cline { 2 - 2 } & Peer Group Social Support \\
\hline \multirow{4}{*}{ Employee } & Work Time Scheduling (Unsocial Hours) \\
\cline { 2 - 2 } Participation & Wours of Work (Duration) \\
\hline & Direct Participation regarding Organisational Decisions \\
\cline { 2 - 2 } & Consultative Committees Works Councils \\
\cline { 2 - 2 } & Union Presence \\
\cline { 2 - 2 } & Union Decision Making involvement \\
\hline
\end{tabular}

\section{Employment}

As noted above, in the initial conceptualisation of QulnnE, employment was of interest as an output, an effect of innovation, and the interaction of innovation and job quality. Three dimensions of employment were of interest: 1) the volume of employment and its fluctuations (total number of jobs and increases/decreases); 2) which types of jobs were created, destroyed, modified or unaltered in terms their task and qualitative content (job quality); and 3) the distribution of these jobs among various categories of social groups (i.e., inclusionary and exclusionary effects on various groups). Where data is available these categories usually include sex, age, nationality/migration status, and education/skill level.

Though initially conceptualised as an output variable, as the project progressed and firmbased qualitative case studies commenced, employment became recognised as a significant factor impacting both innovation and job quality. For example, some innovations could not be implemented or expanded due to understaffing, a lack of skilled personnel, or high personnel turnover (Gautié et al., 2018; Green et al., 2018). On the other hand, high turnover and recruitment problems directly led to innovations to either use existing scarce labour more preciously or develop new recruitment and retention innovations (Keune et al., 2018; Jaehrling et al., 2018; Green et al., 2018; Mathieu et al., 2018). Still other innovations arose not only due to the direct occupational skills of employees, which was expected, but also the personal non-occupational knowledge and abilities of current employees became the basis for sometimes even radical innovations (Martín et al., 2018; Mathieu et al., 2018). So rather than as initially conceptualised in Figure 1, a triangular interactive relation became the operational approach, i.e., not just investigating effects on employment, but also how employment, especially labour shortages, but also the composition of incumbent labour forces, impact innovation processes and job quality, see Figure 3. 


\section{Innovation}

Job quality

Employment

\section{Figure 3. QuInnEs operational approach}

\section{QulnnE studies, findings and results}

In a series of quantitative and qualitative studies the relationship between product, process, and organisational innovation and job quality was analysed in itself, as well as ensuing effects on employment, social inclusion and inequality. An overview of the empirical studies undertaken in the QulnnE project is found in Table 2.

Table 2: Overview of the empirical studies undertaken in the QulnnE project

\begin{tabular}{|c|c|c|c|c|}
\hline Reference* & Method & $\begin{array}{l}\text { Data / } \\
\text { database }\end{array}$ & Countries & $\begin{array}{l}\text { Level of } \\
\text { analysis }\end{array}$ \\
\hline $\begin{array}{l}\text { Duhautois, et al } 2018 . \\
\text { The employment and job quality effects of } \\
\text { innovation in France, Germany and Spain: } \\
\text { evidence from firm-level data. WP } 7\end{array}$ & Quantitative & $\begin{array}{l}\text { CIS, DADS, } \\
\text { FARE, IAB } \\
\text { Establishment } \\
\text { Panel, ESEE }\end{array}$ & $\begin{array}{l}\text { FR, ES, } \\
\text { GER }\end{array}$ & Firm \\
\hline $\begin{array}{l}\text { Erhel C. \& Guergoat-Larivière } 2016 . \\
\text { Innovation and Job Quality Regimes: A Joint } \\
\text { Typology for the EU. WP } 3\end{array}$ & Quantitative & $\begin{array}{l}\text { CIS, EWCS, LFS, } \\
\text { SES, ESAW }\end{array}$ & $\begin{array}{l}22 \mathrm{EU} \\
\text { countries }\end{array}$ & $\begin{array}{l}\text { National/Firm/ } \\
\text { Individual }\end{array}$ \\
\hline $\begin{array}{l}\text { Gallie, } 2018 . \\
\text { Quality of work and innovative capacity: } \\
\text { implications for social equality. WP } 8\end{array}$ & Quantitative & EWCS & EU-15 & Individual \\
\hline $\begin{array}{l}\text { Gautié, et al } 2018 . \\
\text { Innovation, Job Quality and Employment } \\
\text { Outcomes in the Aerospace Industry: } \\
\text { Evidence from France, Sweden and the UK. } \\
\text { Ch } 2 \text { WP } 6\end{array}$ & Qualitative & $\begin{array}{l}\text { Interviews } \\
\text { Firm } \\
\text { documents }\end{array}$ & $\begin{array}{l}\text { FR, SE, } \\
\text { UK }\end{array}$ & $\begin{array}{l}\text { Firm / } \\
\text { Organisational } \\
\text { unit }\end{array}$ \\
\hline
\end{tabular}




\begin{tabular}{|c|c|c|c|c|}
\hline $\begin{array}{l}\text { Green, et al } 2018 . \\
\text { Innovation, Job Quality and Employment } \\
\text { Outcomes in Care: Evidence from Hungary, } \\
\text { the Netherlands and the UK. Ch } 8 \text { WP } 6\end{array}$ & Qualitative & $\begin{array}{l}\text { Interviews } \\
\text { Firm } \\
\text { documents }\end{array}$ & $\begin{array}{l}\mathrm{HU}, \mathrm{NL}, \\
\text { UK }\end{array}$ & $\begin{array}{l}\text { Firm / } \\
\text { Organisational } \\
\text { unit }\end{array}$ \\
\hline $\begin{array}{l}\text { Jaehrling, et al } 2018 . \\
\text { The digitisation of warehousing work. } \\
\text { Innovations, employment and job quality in } \\
\text { French, German and Dutch retail logistics } \\
\text { companies. Ch } 7 \text { WP } 6\end{array}$ & Qualitative & $\begin{array}{l}\text { Interviews } \\
\text { Firm } \\
\text { documents }\end{array}$ & $\begin{array}{l}\text { FR, GER, } \\
\mathrm{NL}\end{array}$ & $\begin{array}{l}\text { Firm / } \\
\text { Organisational } \\
\text { unit }\end{array}$ \\
\hline $\begin{array}{l}\text { Keune, et al } 2018 . \\
\text { Innovation and Job Quality in the Games } \\
\text { Industry in Germany, the Netherlands, } \\
\text { Sweden and the UK. Ch } 6 \text { WP } 6\end{array}$ & Qualitative & $\begin{array}{l}\text { Interviews } \\
\text { Firm } \\
\text { documents }\end{array}$ & $\begin{array}{l}\text { GER, NL } \\
\text { SE, UK, }\end{array}$ & $\begin{array}{l}\text { Firm / } \\
\text { Organisational } \\
\text { unit }\end{array}$ \\
\hline $\begin{array}{l}\text { Makó, et al } 2018 . \\
\text { The relationship between employment, job } \\
\text { quality and innovation in the automotive } \\
\text { Industry: a nexus of changing dynamics } \\
\text { along the value chain. Evidence from } \\
\text { Hungary and Germany. Ch } 3 \text { WP } 6\end{array}$ & Qualitative & $\begin{array}{l}\text { Interviews } \\
\text { Firm } \\
\text { documents }\end{array}$ & GER, HU & $\begin{array}{l}\text { Firm / } \\
\text { Organisational } \\
\text { unit }\end{array}$ \\
\hline $\begin{array}{l}\text { Martín et al } 2018 . \\
\text { Innovation, Job Quality and Employment } \\
\text { Outcomes in the Agri-food Industry: } \\
\text { Evidence from Hungary and Spain. Ch } 4 \text { WP } \\
6\end{array}$ & Qualitative & $\begin{array}{l}\text { Interviews } \\
\text { Firm } \\
\text { documents }\end{array}$ & $\mathrm{ES}, \mathrm{HU}$ & $\begin{array}{l}\text { Firm / } \\
\text { Organisational } \\
\text { unit }\end{array}$ \\
\hline $\begin{array}{l}\text { Mathieu, et al } 2018 . \\
\text { Innovation, Job Quality and Employment in } \\
\text { Hospitals in Spain and Sweden. Ch } 9 \text { WP6 }\end{array}$ & Qualitative & $\begin{array}{l}\text { Interviews } \\
\text { Firm } \\
\text { documents }\end{array}$ & $\mathrm{ES}, \mathrm{SE}$ & $\begin{array}{l}\text { Firm / } \\
\text { Organisational } \\
\text { unit }\end{array}$ \\
\hline $\begin{array}{l}\text { Muñoz-de-Bustillo, et al } 2016 . \\
\text { Innovation and Job Quality: An Initial } \\
\text { Exploration. WP } 5\end{array}$ & Quantitative & EWCS & EU-15 & $\begin{array}{l}\text { National/ } \\
\text { Industry/ } \\
\text { Individual }\end{array}$ \\
\hline $\begin{array}{l}\text { Muñoz-de-Bustillo, et al } 2017 . \\
\text { An approximation of job quality and } \\
\text { Innovation using the } 3^{\text {rd }} \text { European } \\
\text { Company Survey. WP } 4\end{array}$ & Quantitative & ECS & $\begin{array}{l}32 \\
\text { European } \\
\text { countries }\end{array}$ & Firm \\
\hline $\begin{array}{l}\text { Perez and Martín } 2018 . \\
\text { Digitalisation and Artificial Intelligence: the } \\
\text { New Face of the Retail Banking Sector. } \\
\text { Evidence from France and Spain. Ch } 5 \text { WP } 6\end{array}$ & Qualitative & $\begin{array}{l}\text { Interviews } \\
\text { Firm } \\
\text { documents }\end{array}$ & $E S, F R$ & $\begin{array}{l}\text { Firm / } \\
\text { Organisational } \\
\text { unit }\end{array}$ \\
\hline
\end{tabular}

* WP denotes QulnnE Working paper number; Ch denotes chapter in QulnnE Working Paper No. 6 (Jaehrling ed., 2018). Virtuous circles between innovations, job quality and employment in Europe? Case study evidence from the manufacturing sector, private and public service sector.)

As stated above, the quantitative studies were carried out using datasets comprising individual, firm, industry and national level data, and range from analyses of three countries 
(Germany, France and Spain) to the EU-28 plus Iceland, Turkey, Macedonia and Montenegro. These studies largely found correlations between "technological innovations," especially product innovation, but also process innovation, and improved job quality and increased employment. The association between organisational innovation and job quality was more ambiguous, likely due, as noted, to the heterogeneity contained in the Oslo Manual's (2005) rendering of the concept. As all but one of the studies were cross-sectional, causality could normally not be established.

The qualitative studies were undertaken in eight industries or branches across seven countries (see Table 3), in order to investigate the mechanics of the interaction between various types of innovation, job quality, and employment.

Table 3: Number of case studies and interviews per industry and country.

\begin{tabular}{|l|l|l|l|l|l|l|l|l|l|l|}
\hline & UK & FR & NL & SE & ES & HU & GER & $\begin{array}{l}\text { Total number } \\
\text { of case studies }\end{array}$ & \begin{tabular}{l} 
interviews number of \\
\hline Manufacturing sector
\end{tabular} \\
\hline Aerospace & 1 & 3 & & 2 & & & & 6 & \\
\hline Automotive & & & & & & 3 & 2 & 5 & 78 \\
\hline Agri-food & & & & & 4 & 3 & & 7 & 34 \\
\hline Private Service Sector & & & & & & \\
\hline Computer games & 2 & & 6 & 3 & & & 3 & 14 & 59 \\
\hline Banking & 3 & & & 2 & & & 5 & 86 \\
\hline Retail Logistics & & 2 & 2 & & & & 3 & 7 & 42 \\
\hline (quasi) Public Sector & & & & & & 52 \\
\hline Elderly / Home care & 3 & & 2 & & & 3 & & 8 & 56 \\
\hline Hospitals & & & & 4 & 2 & & & 6 & 54 \\
\hline TOTAL & 6 & 8 & 10 & & 8 & 9 & 8 & & 461 \\
\hline
\end{tabular}

Source: Jaehrling (2018, p. 13)

When looking at aggregate data on firms in these industries across the $\mathrm{EU}^{2}$, crossing innovation with job quality three clusters emerge: industries characterised by low innovation and low job quality (Food production and Social care); high innovation and low job quality (Retail logistics), and high innovation and high job quality (Hospitals, Aerospace, Automobile manufacturing, Computer games and Retail banking). This is presented in Table 4 below:

\footnotetext{
${ }^{2}$ This refers to data based on aggregate data on firms in these industries across the EU, and does not necessarily reflect the situation in the individual firms studied in the case studies.
} 
Table 4: Relationship between job quality and technological innovation

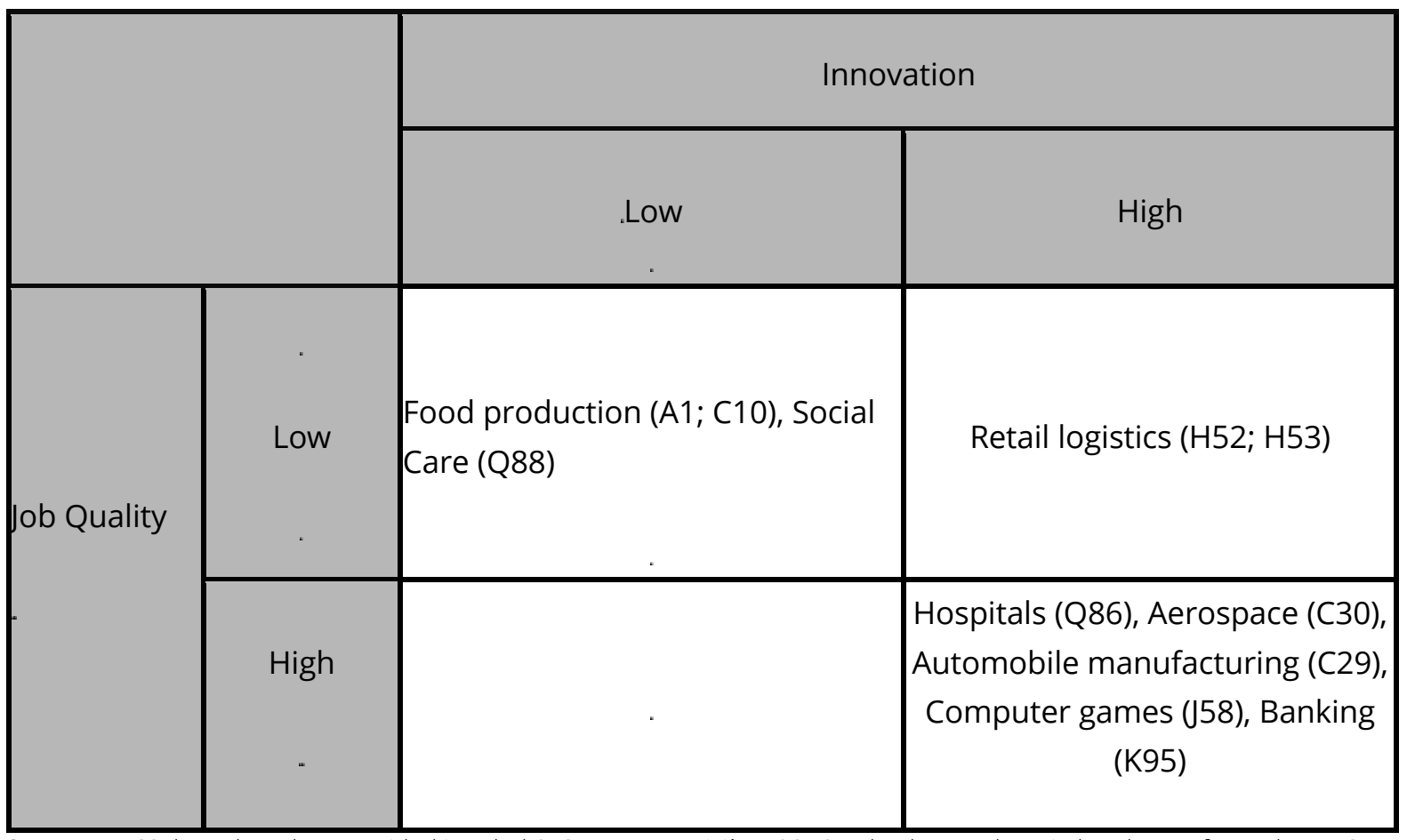

Source: EWCS (based on data provided in Erhel \& Guergoat-Larivière, 2016). Nb. The numbers in brackets refer to the NACE codes for the respective industries under study.

Below, QulnnE findings are presented thematically, drawing on both the quantitative and qualitative studies, first focusing on the relationship between innovation and job quality, then presenting results on employment and labour market inclusion. Detailed methodological discussions and further findings are found in the respective publications referenced for each study.

\section{The Innovation-Job Quality Relationship}

Using microdata from the 2010 European Working Conditions Survey (EWCS) Muñoz de Bustillo et al. (2016) constructed a job quality index consisting of five dimensions:

- $\quad$ pay (gross monthly wage in Purchasing Power Parity);

- intrinsic job quality (skills, autonomy, personal support);

- employment quality (contract stability and development opportunities);

- health and safety; and

- working time and work-life balance (duration and scheduling of hours and intensity of work).

The analysis conducted on the EU-15 found a positive and statistically relevant relation between innovation and the job quality index ( $R 2=0.366)$. Analysis of the five individual components of the job quality index found that the relation was very high for intrinsic job quality and employment quality, and lower for health and safety, and work-life balance. The 
relation between pay and innovation was difficult to assess, due to difference in per capita GDP in the EU-15 countries in explaining wage differences. The findings identifying intrinsic job quality (skills, autonomy, support); and employment quality (contract stability and development opportunities) are found in other QulnnE studies, and the broader literature that identify employment stability, training and development, and support, autonomy and discretion as key aspects of the generative interaction between job quality and innovation (De Spiegelaere, 2014; 2016; Foss, 2005; Laursen \& Foss, 2014; Lorenz, 2015; Lorenz \& Valeyre, 2005; Lundvall \& Lorenz, 2012; Asheim \& Parrilli, 2012). Even in individual-level analysis controlling for variations in job quality associated with country, age, sex, education, industry, occupation, and firm size, both types of technological innovation proved significantly and positively correlated to job quality, while organisational innovation had no impact when controls were applied. The latter result can be interpreted as organisational innovation having neither a beneficial nor detrimental effect, or that organisational innovations comprise both beneficial and detrimental effects, but that on aggregate these cancel-out each other.

In another study using the 2010 ECWS, Gallie (2018) investigated the relationship between job quality and innovation by analysing what type of employees were engaged in innovation activities. Gallie constructed an "innovation-conducive job quality index," based on findings of previous research comprising three dimensions: 1) training and informal learning-based knowledge development; 2) scope for individual task discretion and use of initiative; and 3) job security. Analysing where employees were on this index from high to low, Gallie compared this against responses to the 2010 EWCS item about engagement in innovationoriented activities, asking how much time the respondent was "involved in improving the work organisation or work process of your department or organisation." Gallie (2018) found a striking difference. Whereas 66\% of those high on the index, i.e. those enjoying high degrees of training and knowledge development, discretion, and job security, were involved in innovation or improvement activities, only $14 \%$ of those low on the index were engaged in such activities. This profound polarisation witnesses to the correlation between the enjoyment of high job quality and engagement in innovation activities and poor job quality and non-engagement in innovation activities.

Muñoz de Bustillo et al. (2017) carried out another cross-sectional study to probe the link between innovation and job quality on an even larger sample (EU-28, plus Iceland, Turkey, Macedonia and Montenegro) using firm-level data from the 2013 European Companies Survey (ECS). The ECS contains indicators for intrinsic job quality, employment quality, worklife balance and worker participation, but nothing on pay or health and safety. From these dimensions Muñoz de Bustillo et al. (2017), constructed a "Summary Index of Job Quality"4 (SIJQ). A first analysis found positive relationships for all types of innovation and the SIJQ before controls were applied. When controls were applied for firm size, percentage of female

\footnotetext{
${ }^{3}$ An extended analysis from this study is found in Grande et al., 2020.

${ }^{4}$ See p.6 of Muñoz de Bustillo et al., 2017 for the items from the ECS 2013 and their weighting for the Summary Index of Job Quality applied in this study.
} 
employees, share of employees with university education, use of outsourcing, whether the organisation was public or private, an autonomous or headquarter unit or a subsidiary, only process innovation was strongly significant in relation to job quality with product innovation being significant only at the $10 \%$ level. Organisational innovation became non-significant. This study made two uniquely important findings. The first being that, in firms with a union representative, both process and organisational innovation were significantly positively associated with job quality, while this was absent in firms without union representation. Formal worker organisation and representation was thus found to play an important moderating role especially between organisational innovation and job quality. The second is that firms that have recent experience of downsizing or workforce reductions had lower job quality. This supports the contention for seeing employment not merely as an output of the interaction of innovation and job quality, but also as a factor impacting job quality and innovation (see the discussion of qualitative findings below where understaffing in hospitals and social care reduces both job quality and innovation).

Duhautois et al. (2018) analysed the impact of innovation on job quality and employment (employment results are discussed in the next section) using large sample firm-level data from Germany ( $n=9416$ public and private, all industries), France ( $n=14204$, private sector only) and Spain ( $n=1857$ manufacturing only). The time period for investigation was 20092013 for Germany and France, and 2002-2010 for Spain for data quality reasons. Thus, the timeframe for the German and French analyses are identical and cover the period after the 2008-2009 global financial crisis. The period for Spain is longer, and covers the period before and during the GFC. The job quality variables in this study comprise pay, skill level, and contractual job security. In France and Germany product innovation led to higher wages and increased job security (measured directly in Germany via turnover and indirectly for France), and an increase in higher-skilled workers in French firms and increases in skilled and nonskilled jobs in Germany. Process innovation decreased job quality in France as measured through an index comprising contract duration, hours of work, hourly wages, and gender pay gap, while in Germany it increased pay, reduced turnover, but did not increase skilled jobs and increased the use of part-time workers. Organisational innovation was found to have negative consequences. In France it had a negative impact on wages, while in Germany it increased the number of low-paid workers. Significantly, the fact that these studies were longitudinal allows the inference that the relationship between innovation and job quality is causal. The positive impact of innovation on permanent contracts and working hours was further corroborated again using longitudinal data for France by Duhautois et al. (2020).

Erhel \& Guergoat-Larivière (2016) used principal component analysis on indicators from several European datasets rendering comparable data for 22 EU states to analyse correlations between job quality indicators found in Table 1 and innovation indicators. They then identify country clusters using Hierarchical Ascending Classification (HAC). The two clusters are then crossed, rendering Table 5 below. This analysis shows that with some exceptions: most notably Estonia, which has good innovation performance, but far worse job quality than expected for its innovation performance, there is a general alignment 
between job quality and innovation. The seven populated quadrants reoccur in Table 6 below when examining employment outcomes for different segments of the workforce.

Table 5: Crossing job quality clusters and innovation clusters (2012)

\begin{tabular}{|l|l|l|l|l|l|}
\hline & \multicolumn{2}{|l|}{ Innovation } & & \\
\hline & & -- & - & + & ++ \\
\hline \multirow{4}{*}{ Job quality } & ++ & & & & DK FI SE \\
\cline { 2 - 6 } & + & & & AT DE IE NL UK BE LU & \\
& - & ES PL & EL IT PT & FR & \\
\cline { 2 - 6 } & -- & CZ LT LV SK HU & & EE & \\
\hline
\end{tabular}

Source: Erhel \& Guergoat-Larivière (2016)

Also using national clusters to bolster number of observations and several waves of the ECWS, Gallie (2018) analysed the period 2005-2015 to investigate the impact of innovation and job quality on various segments of the workforce. Applying the same index of "innovation conducive job quality" presented above to seven national clusters ${ }^{5}$, Gallie found that overall higher ICJQ jobs were becoming more prevalent across Europe and that a degree of convergence between clusters has taken place. A further finding was a consistent decline in ICJQ for workers on temporary contracts in the EU-15 clusters. The study also found a stable and equal distribution of ICJQ jobs between men and women, while ICJQ jobs are predominately held by workers between the ages of 35-49.

With quantitative analysis seeking to measure the strength of association between forms of innovation and dimensions of job quality, QulnnE's qualitative analyses examined how these linkages played out at the workplace level. In case studies both directions of the relationship were examined, that is, how innovations impact job quality and how job quality impacts innovation. As radical innovation is infrequent, the primary form of innovation found and investigated in the qualitative studies is incremental innovation. As the effects of organisational innovations were largely ambiguous and opaque in the quantitative studies, the qualitative analyses sought to examine consequences of organisational innovations on job quality as well as how aspects of job quality facilitated or hindered organisational innovation.

One of the organisational innovations found in several case studies was the introduction of established innovation-promoting management programmes: Lean in manufacturing and healthcare (Makó et al., 2018; Mathieu et al., 2018); the liberated firm in aerospace (Gautié et al., 2018); and agile/scrum in the computer games industry (Keune et al., 2018)). In these cases, codified knowledge management programmes derived from management science are implemented in order to promote the Doing, Using and Interacting (DUI - Jensen et al., 2007) innovation mode based on immanent, tacit and discretionary learning knowledge production

\footnotetext{
${ }^{5}$ Not the seven clusters found in Tables 5 and 6. Gallie's clusters are: The North West (UK and Ireland); Nordic, Continental; and Mediterranean among the EU-15 states; and the North East; Central East; and South East among the New Member States. See Gallie 2018, p. 11 for the list of countries in each cluster.
} 
(Lorenz, 2015). As noted by Gallie (2018) these variants on High-Involvement or HighPerformance Work Systems promote worker participation in the innovation process and job quality simultaneously. The introduction of these management programmes underlines the importance of incremental innovation (Mathieu and Warhurst 2018) in line with the DUI innovation mode, especially in mature fields where radical innovations are less likely due to an emphasis on exploitation rather than exploration (March 1991). Such conditions were reported particularly in the aerospace (Gautié, et al., 2018) and automotive industries (Makó et al., 2018). where firms in particular positions in value or supply chains are locked into an established technological configuration network.

In the qualitative studies, the linchpin in the connection between job quality and innovation centres around worker participation. As mentioned above, many of the managerial innovations introduced were aimed at promoting participation via two-way communication channels between managers and workers, and exploration and experimentation. The former often took the form of well-known mechanisms such as regular meetings between managers and workers that are part of agile, scrum, and lean processes; employee suggestion channels and competitions; and co-locating cross-occupational development groups. Regarding employee exploration and experimentation, nowhere was managerial support for this greater than in the computer games industry towards game developers. Here continuous individual and collective problem-solving was required and high degrees of discretion were accorded individuals and workgroups to accomplish their essentially creative tasks (Keune et al., 2018). Further evidence of employee participation and managerial support for employee discretion in this industry is the extensive use of firm-external knowledge networks among developers.

A significant finding in other industries where design and execution are separated (in contrast to computer games development work) was the role of two-way communication channels, allowing implementation employees to question, comment on, and make suggestions back into the design phase of the processes they were to implement. This erodes the classic linear design-implementation dichotomy and division of labour. This was found most explicitly in the aerospace industry with the introduction of 3D CAD/CAM or digital blueprints, where comments could be made directly back to design engineers via the same technology platform (Gautié et al., 2018). Similar technologies also facilitated workers at automotive OEMs to communicate with suppliers (Makó et al., 2018). Similar activities took place in services, notably in social and health care, but based on a social rather than technological channels (Green et al., 2018). Opening up technologies and social spaces for contributions from employees further along the production process turned this from a linear to a looped process. This shifts the innovation contributions, from the workers' very proximate task operations to decisions more distant and profound in their implications than the immediate realm of the given employee. Routine task performance is punctuated by creative contributions. These are situations where more durable, often incremental contributions were made. This can be contrasted with situations where creative contributions were either continuously demanded and required as in the computer games 
industry (Keune et al., 2018), or in the banking industry where customer service agents continuously modified and "personalised" standard Al-generated replies to customers (Perez \& Martín, 2018).

Participatory incremental innovation contributions are most likely in work processes that can be improved through familiarity, knowledge, and are malleable: i.e., those work processes not entirely scripted, rote, fixed and simplified beyond development. This is likely a major element behind Gallie's (2018) finding that only 14\% of workers in low-skill jobs are engaged in innovation activities, whereas two-thirds of those in high-skilled jobs are. High-skill jobs are likely more developable contrasted with Taylorised low-skilled jobs. It is also likely that lowerskilled workers in these jobs are less frequently invited into innovation processes. Furthermore, such innovation processes require employment stability affording opportunity to acquire deeper understandings of work process, often in dialogue with known and trusted colleagues to share and develop insights and experiences another feature of workplace stability and extended tenure without constant turnover of colleagues. Such factors are more associated with high-skilled than low-skilled work, as evidenced in several of the quantitative analyses discussed above, and the relative absence of employee-driven innovation in the retail logistics cases where the participatory factors discussed above are largely absent (Jaehrling et al., 2018).

The industry where case studies displayed the greatest variation in approaches towards innovation and job quality was social care. At one end there are highly Tayloristic systems, so-called time-and-task approaches where a rigid schedule specifies particular activities to be undertaken by a caregiver in a given order and time allotment. At the other end is a Dutch example of multi-occupational self-governing teams that are given resources and responsibility for a specific geographic area, then accorded tremendous discretion in the planning and execution of care activities in consultation with the recipients. Variants of both high and low-trust/discretion systems were found in the three countries analysed, a variation which is impacted by both basic managerial choices made by firms, as well as the reporting and accounting directives imposed by the (usually municipal) bodies that fund and contract social care services (Green et al., 2018).

\section{The Innovation - Job Quality - Employment Relationship}

In the longitudinal, firm-level analysis conducted by Duhautois et al. (2018) presented above, technological innovation was associated with increased employment in the surveyed firms in France, Germany, and Spain. This holds for product innovation in all three countries, while process innovation increased general employment in France and Spain, while organisational innovation did the same in France and Germany. The findings on process and organisational innovation counter the common understanding of these innovation forms as oriented towards labour-saving workforce rationalisation. Looking at findings for specific categories of employment or types of jobs, skilled jobs increased as a result of product innovation in France, while skilled and unskilled work increased in Germany. In both countries, permanent 
and temporary employment increased. Process innovation increased skilled jobs in France, while in Germany it only increased part-time jobs. Organisational innovation was found to increase employment in France and Germany but have no effect in Spain.

This study shows two important things. First, innovation does not decimate jobs in innovative firms. That is to say, even the innovation forms most suspected of rationalising away jobs, process and organisational innovations, are associated with increased employment in Germany and France, or had no effect (Spain). As the authors point out, this may be a matter of business stealing, where innovative firms take market share from less innovative firms and thereby expand operations and employment. It is also possible that the rate of employment growth in innovative firms might be lower than expected in comparison to the rate of business expansion, but this is difficult to establish. However, the findings show that these innovations are not job destroying. This likely plays a role in innovation promotion and acceptance in innovative firms, and this understanding should be spread. If innovation can be seen as leading to employment creation (or at least not leading to redundancies) and improved job quality, acceptance of and participation in innovation activities is more probable.

The second point is that innovation tends to change the composition of the workforce at the firm level, with technological and organisational innovation favouring high-skilled workers and jobs, while having no or negative impact on lower-skilled work. This is obviously good from a job quality perspective. However, taken together, these two points mean that with innovation more high-skilled jobs and relatively fewer low-skilled jobs are created: supporting the "skill biased technological change" thesis (Autor, Levy \& Murnane 2003; Berman, Bound \& Machin 1998). This increases inequality in society, increases competition for the remaining lower-skilled jobs, and intensifies the need to increase skill levels among citizens to be able to fill the higher skilled jobs created.

Though multiple factors play into national employment rates, Table 6 below showing employment rates in the seven innovation-job quality clusters produced via principal component analysis by Erhel \& Guergoat-Lariviére (2016) contains notable differences. One is that countries with the highest innovation and job quality performance levels also have the highest employment rate for the low educated, while those with the worst innovation and job quality performance have the lowest rates for this educational category. Likewise, the highest innovation and job quality cluster (plus Estonia, the "Innov + JQ --" country) has the highest employment rates for older workers. Universally, the highly educated have rather uniform and high employment rates. 


\section{Table 6: Employment rates by social groups (education, gender, age and nationality) in the seven innovation-job quality clusters (2012 data)}

\begin{tabular}{|l|l|l|l|l|l|l|l|}
\hline & $\begin{array}{l}\text { Innov- } \\
- \text { JQ-- }\end{array}$ & $\begin{array}{l}\text { Innov- } \\
- \text { JQ - }\end{array}$ & $\begin{array}{l}\text { Innov- } \\
\text { JQ - }\end{array}$ & $\begin{array}{l}\text { Innov+ } \\
\text { JQ-- }\end{array}$ & $\begin{array}{l}\text { Innov+ } \\
\text { JQ - }\end{array}$ & $\begin{array}{l}\text { Innov+ } \\
\text { JQ+ }\end{array}$ & $\begin{array}{l}\text { Innov++ } \\
\text { JQ++ }\end{array}$ \\
\hline Low educated & 39,4 & 44,6 & 54,0 & 50,3 & 55,7 & 55,2 & 60,7 \\
\hline $\begin{array}{l}\text { Medium } \\
\text { educated }\end{array}$ & 69,6 & 65,9 & 68,1 & 74,4 & 73,6 & 74,7 & 79,1 \\
\hline High educated & 83,5 & 81,1 & 77,4 & 82,3 & 84,4 & 85,1 & 86,5 \\
\hline Women & 65,3 & 58,5 & 55,3 & 72,2 & 67,5 & 67,8 & 75,6 \\
\hline Men & 75,4 & 71,2 & 71,9 & 78,0 & 76,7 & 79,9 & 80,8 \\
\hline $15-24$ & 22,8 & 21,6 & 18,2 & 32,3 & 28,6 & 40,4 & 45,7 \\
\hline $25-54$ & 77,7 & 72,0 & 69,9 & 79,5 & 80,9 & 80,5 & 83,0 \\
\hline $55-64$ & 46,6 & 41,3 & 41,1 & 60,5 & 44,5 & 49,8 & 64,0 \\
\hline EU15-foreigners & 91,0 & 75,2 & 59,9 & - & 70,1 & 74,4 & 76,1 \\
\hline $\begin{array}{l}\text { Non-EU } \\
\text { foreigners }\end{array}$ & 68,3 & 60,6 & 62,6 & 65,6 & 50,6 & 62,2 & 57,8 \\
\hline Nationals & 70,8 & 65,3 & 63,4 & 77,0 & 73,2 & 74,3 & 79,3 \\
\hline
\end{tabular}

Source: Erhel \& Guergoat-Lariviére (2016). Note: This Table corresponds to the innovation-job quality clusters presented in

Table 5 above. The countries found in each of the innovation-job quality clusters can be found in that Table.

In qualitative case studies, own and colleagues' employment and job security were not surprisingly found to be an important factor in employees' actions regarding innovation. This can be seen as individual or group mediation of the innovation-employment relationship. However, innovation suggestions, even those that can lead to work efficiencies and job reductions could be maintained with the right assurances and trust between management and workers. One example of this is from an OEM automotive subsidiary in Hungary where innovation activities were assuredly not part of a cost-efficiency strategy aimed at rationalising away jobs, but a knowledge and quality improvement orientation disseminated from headquarters to move up the supply-chain. Under this approach improving work practices could lead to job transformation and relocation of employees rather than redundancies, thus assuring employee participation in the strategy (Makó et al., 2018).

Several case studies observed less outright job destruction due to innovations than job transformation. Even in retail banking in Spain and France, where workforce reductions transpired due to the shift to online banking, there was case evidence both of banks choosing alternative strategies and maintaining physical branches and tellers (and staff levels), as well as strategies where the closing of bank branches led in part to workforce reductions, but also teller jobs being converted either to pure telecommunications-based customer assistance, or hybrid jobs combining both physical teller activities with telephone or chat customer assistance work (Perez \& Martín, 2018). Likewise, cases in the aerospace industry show tasks either being recombined in new ways, or novel tasks or technologies being introduced alongside existing or traditional tasks and activities after innovation (Gautié et al., 2018). These findings augment well the quantitative studies' findings above that innovative firms 
tend to add (where retention and transformation plays a key role) rather than reduce jobs. As established above this is not just with product innovation, but also with process and organisational innovations, when an unambiguous result appears for the latter. This pattern of some jobs being shed, others being transformed, while new jobs and occupations arise in innovating firms (such as technicians in retail banking, Perez \& Martin, 2018) was seen across industries, with the transformed and new jobs in general being of higher job quality and requiring higher qualifications (Jaehrling et al., 2018). This further supports the skill-biased technological change thesis.

Some cases also found that the retention of employment levels is not just a matter of the inevitable robotic replacement human labour having yet to arrive. Cases in the British aerospace (Gautié et al., 2018) and German automotive parts-supplier industries even show a reversion from automated production processes to "the smart use of manual labour" especially for small-batch, high-end, "craft" products (Makó et al., 2018). In these two cases investment in automation was ostensibly to lower costs and improve quality, but these case firms found overinvestment risks in automation, with return to manual production practices for cost and quality reasons. While these are examples of niche production in particular firms, it shows that, even in manufacturing, trends towards robotics and automation are not universal and inevitable. In retail logistics, the fully automated warehouse remains an unrealised goal, with partially automated or traditional warehouses where technological assisted human product-picking is the norm (Jaehrling et al., 2018). However, there are also cases, such as a Hungarian pasta producer, where automation not just led to a reduced labour force, but also a vast change it its composition, from a previously female-dominated production staff to male engineers operating the new machines (Martín et al., 2018). The new jobs at the pasta factory became more skilled, and more male, and the case study also showed an increased emphasis on work-safety, another dimension of improved job quality.

Some innovations can potentially open up workplaces to previously excluded groups. But countervailing trends can erode these possibilities. In the retail logistics sector assistance with heavy lifting and lower skill demands could be expected to reduce age, sex, and educational bias in warehouse work. However, intensification of work, repetitive tasks, and other types of mental and physical strain, and especially the demand for employees to work firm-friendly flexible schedules and shift-work creates problems for persons with domestic care responsibilities and sensitivity to physical and mental strain (Jaehrling et al., 2018). Thus, while some innovations may open up possibilities for more inclusive employment at workplaces, if they are coupled with innovations, changes, or even the retention of unfavourable measures and practices, the potential of the advantageous innovations can be negated, and with them any possibilities for more inclusive employment. Therefore, it is important to look beyond specific innovations, and to the configuration of practices and conditions obtaining at workplaces. For example, in social care cases in the UK, planning, scheduling, and logistics apps made time and travel management more efficient, but it was also found that more formal and sophisticated reporting systems required increased written communication skills, not to carry out the work per se, but rather to document and report 
work (Green et al., 2018; Mathieu et al., 2020). The latter further restricts recruitment and employment opportunities especially for individuals with low formal education and for whom English is a second or third language in a branch already suffering from recruitment problems and labour shortages.

One way of addressing labour shortages within particular occupational categories in the healthcare sector is through task-shifting. Task-shifting entails moving tasks from an overburdened and scarce occupational group, onto other occupational groups which are easier to recruit. Examples from the Swedish hospital sector show that this can result in new occupational groups working on hospital wards (Mathieu et al., 2018; Mathieu et al., 2020). In some cases, tasks are taken from nurses, an occupational group currently in short supply in Sweden, and given to higher or equal-status occupations, or lower-skill groups. In one case, preparing medicines was shifted from nurses to a comparable-status occupation pharmacists, while preparing milk for infants on a neonatal ward was shifted from nurses to persons without a nursing degree employed just for this task.

In other cases, recruitment to occupations suffering labour shortages became the object of innovations, often organisational innovations. Taking examples again from the hospital sector, a Swedish hospital created an "internal temporary work agency" to offer working conditions that somewhat mimic commercial temporary work agencies (slightly higher wages, more control over scheduling, moving fluidly between wards and departments without strong social ties) in order to retain employees who might be tempted to work for commercial agencies and lure agency workers over to direct employment at the hospital. The same hospital also initiated a new recruitment programme to bring low-qualified youth into jobs at the hospital that can lead to ascending an evident occupational ladder (Mathieu et al., 2018).

A further way in which employment was found to impact innovation (as well as simultaneously decreasing job quality) has to do with staff shortages inhibiting innovation. The normal mechanism for this is through work intensification, due to having to cover for absent colleagues resulting from insufficient staffing levels. Under such circumstances intensified production activities take time, and physical, mental, and emotional energy from innovation development and implementation activities. Such circumstances were reported in cases especially in social care, hospitals, and aerospace as the result of chronic understaffing (Gautié et al., 2018; Green et al., 2018; Mathieu et al., 2018). These are cases of immediate disruption of innovation by employment factors. More medium and long-term effects run through work intensification hindering both external and internal training and development activities and high employee turnover. 


\section{Discussion and policy and strategy implications}

As a collective body of research, the quantitative and qualitative QulnnE studies provide evidence of the mutual generative relationship between innovation, job quality and employment. Furthermore, the in-depth case studies display how these interactions play out at the firm level.

Regarding the association between innovation and job quality, Muñoz de Bustillo et al., (2016) found a positive and significant correlation between both types of technological innovation, but not organisational innovation and job quality. In further analysis in the same study of which aspects of job quality are associated with innovation, they found very high correlation for intrinsic (skills, autonomy, personal support) and employment (contract stability and development opportunities) job quality, with moderate outcomes for health and safety and work life balance. In a subsequent study, Muñoz de Bustillo et al., (2017) found similar results, with process innovation being strongly correlated to job quality, while product innovation weaklier correlated, and organisational innovation insignificant.

Using large firm-level datasets for France, Germany and Spain, Duhautois et al. (2018) also analysed which types of innovation are associated with positive and negative effects on different aspects of job quality. Product innovation increased wages, skilled jobs, and job security in France and Germany, while also increasing non-skilled jobs in Germany. Process innovation increased pay, lowered turnover, and increased part-time jobs in Germany while having negative effects on wages and employment conditions in France. Organisational innovation had a negative impact on wages in France, while increasing low-paid jobs in Germany.

The general conclusion from these transnational studies is that technological innovation is associated with better job quality, though not obtaining for example for process innovation in France. The results for organisational innovation are largely ambiguous or negative, at least in the case of France according to Duhautois et al. (2018). Significant to the latter is Muñoz de Bustillo et al.'s (2016) finding that worker representation and organised labour tips the valence of organisational innovations towards more favourable for job quality, underscoring the opportunity for effects to be changed under specific institutional and action circumstances. Thus, outcomes are not predetermined, but swayed by the agency of differently empowered actors under specific industrial relations regimes. This was most evidently illustrated in the cases on aerospace (Gautié et al., 2018) and retail logistics (Jaehrling et al., 2018) discussed above. Employee participation is therefore not just important for increasing innovation, but also at a collective level in ensuring that innovation takes place in a more equitable manner. This two-fold dimension of participation should be recognised and promoted both in policy and strategy.

Another way in which innovation and job quality are linked is demonstrated in Gallie's (2018) finding that incumbents in jobs high in "innovation-conducive job quality" (ICJQ) elements 
(training and learning; task discretion and initiative; and job security) are 4.7 times more likely to be engaged in innovation activities than those low in these job quality factors. This also displays the gravity of the gap between the inclusion of high-skill workers in innovation activities and the exclusion low-skill workers from innovation activities. Qualitative studies discerned some of the mechanisms behind this result. One is that employees in low-skilled work are not invested with the required level of training, skill-development, tenure at work, and decision latitude to develop innovation contributions. A second is disenfranchisement due to lack of employee motivation to participate in innovation activities, as a result of a feeling of lack of investment and trust in them by management as innovation actors. A third is low job quality employees being in jobs and having tasks so rigidly controlled ("Taylorised") that they are only developable through system-changes from above (Jaehrling et al., 2018). A more universal factor found across industries inhibiting innovation that may disproportionately impact workers with lower ICJQ is work intensification. The reversal of the listed conditions becomes a recipe for increasing the propensity for innovation.

While another of Gallie's (2018) findings, a longitudinal trend towards an increase in ICJQ jobs in the EU from 2005-2015, and convergence between regions, is positive, a further finding should be more worrying to policy makers and corporate leaders. This is the that temporary jobs are decreasing in ICJQ, i.e., temporary jobs were found to be continuously declining, in terms of the aspects of job quality that contribute most to innovation processes. Thus, the move to more "flexible" workforce use erodes innovation capacity, corroborating the findings of Beugelsdijk (2008; also, Zhou et al., 2011), in addition to being a general job quality problem. There appears to a trade-off between flexibility and innovative capacity, and policy makers should consider what it might take to tip the balance in favour of more secure employment forms for its associated benefits.

Regarding employment, the most significant and consistent finding of the QulnnE project is that innovative firms have been shown to add rather than reduce the number of jobs. As discussed above, these are generally higher quality, higher skill (and therefore also higher qualification) jobs. QulnnE's studies thus provide evidence for the skill-biased technical change (SBTC) thesis. The positive dimension in improving job quality and employment should be lauded, but at the same time SBTC will increase inequalities in society through a general Matthew effect on work and labour markets with more jobs for the highly skilled, leaving the less skilled further behind either in unemployment or diminished quality jobs. Policymakers and citizens must recognise that innovation will not solve inequality, it will likely exacerbate it. Thus, inequality needs to be addressed directly with concerted policies for skill upgrading and not via hopes that innovation will not just assist growth, competitiveness, and employment, but also mitigate inequality. The QulnnE results indicate that it won't.

More encouraging, especially with regard to the topic of sustainable work and employment, is the finding that innovation when coupled with high job quality does not appear to push older workers out of the labour force. Rather the opposite seems to be the case. The countries enjoying such conditions are in the Nordic region, and their rather unique labour- 
relations institutions likely play a role in this outcome (see Table 6 above and Erhel \& Guergoat-Lariviére, 2016). Though it may be considered either anecdotal or telling, an example from the aerospace cases illustrates two different approaches in two different labour relations regimes. Faced with a very similar transition to implementing new production technology and the need for a more technologically sophisticated workforce in tight labour markets for skilled workers, a French firm chose to grant early retirement to the impacted employees and recruit new employees with "higher" qualifications. In close consultation with unions, a Swedish firm in the same situation at the same time largely retained and retrained its workforce (Gautié et al., 2018). This is further evidence that labour relations and institutions as well as firm choice play important roles in moderating the effects of innovations and a policy lesson for how this model of investment in training and skills upgrading can benefit a potentially vulnerable segment of the workforce.

\section{Conclusion}

QulnnE's empirical results affirm two encouraging effects of innovation. The first is that innovating firms increase employment. This result is not surprising for product innovation, which can reasonably be assumed to lead to increased market share and new market opportunities. More surprising is that it also holds for process innovation, where one would job-shedding due to rationalisation. The result regarding employment is unreservedly positive, and should be publicised to counter a widely spread notion that innovation leads to rationalising away of employment opportunities.

The second effect is that innovation tends to result in better quality jobs. This is also positive in and of itself. However, in line with the skill-biased technological change thesis, it creates greater disparities in society by disproportionately creating higher-end jobs for higher-skilled workers. This means that, left to itself, without compensatory actions, innovation will increase disparities in society. In other words, innovation should not be relied upon to increase social inclusion in the labour market and provide a broad spectra of employment opportunities. A logical two-pronged policy approach would be to ensure that as many people as possible can acquire higher skill-levels that match the demands for the jobs that innovation tends to create, while at the other end, securing the existence of jobs that lower skilled workers can enter the labour market with and develop in. Firm internal competence-development and job-ladders as well as external training will be needed to ensure that labour capabilities match future job demands.

Particular job quality factors have been found in both quantitative and qualitative studies to be significant in the innovation process, especially skills, autonomy, personal support, job security/contract stability competence development opportunities experimentation and voice and participation, but also scheduling and work life balance and ergonomic factors. A key conclusion from QulnnE is that in general there is not a high-road and a low-road to innovation, but rather a road to high innovation and a road to low innovation. The former is 
characterised by high job quality, and the latter by low job quality. The exception appears to be for retail logistics and similar branches, where technological and organisational innovations are developed and implemented in a top-down manner, usually with deteriorating job quality as a consequence and with little chance for innovation from below. Contrary to deterministic prognoses, especially the case study findings show that firms can choose, and be guided towards the higher job quality, higher innovation road.

\section{Acknowledgement}

This article and much of the research cited in it was made possible by a grant from the European Commission's Horizon 2020 programme to the project QulnnE - Quality of Jobs and Innovation Generated Employment Outcomes (grant number 649497). The studies and findings are a result of the entire QulnnE team of researchers. We also thank the project's advisory board members for constructive criticism and comments throughout the project.

\section{References}

Asheim, B. \& Parrilli, M. (eds) (2011). Interactive learning for innovation. A key driver within clusters and innovation systems. London: Palgrave Macmillan.

Autor, D. H., Levy, F., \& Murnane, R. J. (2003). The Skill Content of Recent Technological Change: An Empirical Exploration. The Quarterly Journal of Economics, 118(4), 1279-1333.

Berman, E., Bound, J. \& Machin, S. (1998). Implications of Skill-Biased Technological Change: International Evidence. The Quarterly Journal of Economics, 113(4), 1245-1279.

Beugelsdijk, S. (2008). Strategic human resource practices and product innovation. Organisation Studies, 29(6), $821-847$.

Brynjolfsson, E. and McAfee, A. (2011). Race against the machine: how the digital revolution is accelerating innovation, driving productivity, and irreversibly transforming employment and the economy. Lexington, MA: Digital Frontier Press.

De Spiegelaere, S., Van Gyes, G., De Witte, H., Niesen, W., \& Van Hootegem, G. (2014). On the Relations of Job Insecurity, Job Autonomy, Innovative Work Behaviour and the Mediating Effect of Work Engagement. Creativity and Innovation Management, 23(3), 318- 330.

De Spiegelaere, S., Van Gyes, G. \& Van Hootegem, G. (2016). Not All Autonomy is the Same. Different Dimensions of Job Autonomy and Their Relation to Work Engagement \& Innovative Work Behaviour. Human Factors and Ergonomics in Manufacturing and Service Industries, 26(4), 515-527.

Duhautois, R., Erhel, C., Guergoat-Larivière, M., Mofakhami, M., Obersneider, M., Postels, D., Anton, J., Muñoz de Bustillo, R., \& Pinto, F. (2018). The Employment and Job Quality Effects of Innovation in France, Germany and Spain: Evidence from firm-level data. QulnnE Working Paper No. 7. Available at: http://quinne.eu

Duhautois, R., Erhel, C., Guergoat-Larivière, M. \& Mofakhami, M., (2020). More and Better Jobs, But Not for Everyone: Effects of Innovation in French Firms. Industrial and Labor Relations Review, 1-27. DOI: $10.1177 / 0019793920925806$

Erhel, C. \& Guergoat-Larivière, M. (2016). Innovation and Job Quality Regimes: A Joint Typology for the EU. QulnnE Working Paper No. 3. Available at: http://quinne.eu

European Commission. (2010). EUROPE 2020: A strategy for smart, sustainable and inclusive growth. Available at: https://ec.europa.eu/eu2020/pdf/COMPLET\%20EN\%20BARROSO\%20\%20\%20007\%20\%20Europe\%202020\%20-\%20EN\%20version.pdf

Foss, N. (2005). Performance and Organization in the Knowledge Economy: Innovation and New Human Resource Management Practices. Strategy, Economic Organization, and the Knowledge Economy: The Coordination of Firms and Resources. Oxford: Oxford University Press, 187-209. 
Frey, C.B. \& Osborne, M. (2017). The future of employment: How susceptible are jobs to computerisation? Technological Forecasting and Social Change, 114, 254-280.

Gallie, D. (2018). Quality of work and innovative capacity: Implications for social equality. QulnnE Working Paper No. 8. Available at: http://quinne.eu

Gautié, J., Ahlstrand, R., Green, A., \& Wright, S. (2018). Innovation, Job Quality and Employment Outcomes in the Aerospace Industry: Evidence from France, Sweden and the UK. in K. Jaehrling (ed) Virtuous circles between innovations, job quality and employment in Europe? Case study evidence from the manufacturing sector, private and public service sector, 36-87. QulnnE Working Paper No. 6. Available at: http://quinne.eu

Godard J (2004) A critical assessment of the high-performance paradigm. British Journal of Industrial Relations $42(2), 349-378$

Grande, R., Muñoz de Bustillo, R., Fernández Macías, E., and Antón, J. I. (2020). Innovation and job quality. A firmlevel exploration. Structural Change and Economic Dynamics, 54, 130-142.

Green, A., Illéssy, M., Koene, B., Makó, C. \& Wright, S. (2018). Innovation, Job Quality and Employment Outcomes in Care: Evidence from Hungary, the Netherlands and the UK. In K. Jaehrling (ed), Virtuous circles between innovations, job quality and employment in Europe? Case study evidence from the manufacturing sector, private and public service sector, 333-386. QulnnE Working Paper No. 6. Available at: http://quinne.eu

Jaehrling, K. (2018). Prospects for Virtuous Circles? The institutional and economic embeddedness of companies' contemporary innovation strategies in Europe. In K. Jaehrling (ed), Virtuous circles between innovations, job quality and employment in Europe? Case study evidence from the manufacturing sector, private and public service sector, 1-34. QulnnE Working Paper No. 6. Available at: http://quinne.eu

Jaehrling, K., Gautié, J., Keune, M., Koene, B., \& Perez, C. (2018). The digitisation of warehousing work. Innovations, employment and job quality in French, German and Dutch retail logistics companies. In K. Jaehrling (ed), Virtuous circles between innovations, job quality and employment in Europe? Case study evidence from the manufacturing sector, private and public service sector, 280-332. QulnnE Working Paper No. 6. Available at: http://quinne.eu

Jensen, M.B., Johnson, B., Lorenz, E., \&Lundvall, B.-A. (2007). Forms of Knowledge and Modes of Innovation. Research Policy, 36(5), 680- 93.

Keune, M., Payton, N., Been, W., Green, A., Mathieu, C., Postels, D., Rehnström, F., Warhurst, C., \& Wright, S. (2018). Innovation and Job Quality in the Games Industry in Germany, the Netherlands, Sweden and the UK. In K. Jaehrling (ed), Virtuous circles between innovations, job quality and employment in Europe? Case study evidence from the manufacturing sector, private and public service sector, 234279. QulnnE Working Paper No. 6. Available at: http://quinne.eu

Laursen, K., \& Foss, N. (2014). Human Resource Management Practices and Innovation. In M. Dodgson, D. Gann, \& N. Phillips, (eds), The Oxford Handbook of Innovation Management. Oxford University Press, 506529.

Lorenz, E. (2013). Innovation, work organisation and systems of social protection. In E S. Andersen, J. Fagerberg \& B. R. Martin (eds.), Innovation Studies: Evolution and Future Challenges, Oxford: Oxford University Press.

Lorenz, E. (2015). Work Organisation, Forms of Employee Learning and Labour Market Structure: Accounting for International Differences in Workplace Innovation. Journal of the Knowldege Economy, 6(2), 437-466.

Lorenz, E. \& Valeyre, A. (2005). Organisational Innovation, Human Resource Management and Labour Market Structure: A Comparison of the EU-15. The Journal of Industrial Relations, 47(4): 424-442.

Lundvall, B.-A. (ed.). (1992). National systems of innovation: Towards a theory of innovation and interactive learning. London: Pinter.

Lundvall, B-Å. \& Lorenz, E. (2011). Innovation and Competence Building in the Learning Economy: Implications for innovation Policy. In M. B. Asheim and M. Parrilli (eds), Interactive learning for innovation. A key driver within clusters and innovation systems. Palgrave Macmillan, 33-71.

Makó, C., Illéssy, M., \& Latniak, E. (2018). The relationship between employment, job quality and innovation in the automotive Industry: a nexus of changing dynamics along the value chain. Evidence from Hungary and Germany. In K. Jaehrling (ed), Virtuous circles between innovations, job quality and employment in Europe? Case study evidence from the manufacturing sector, private and public service sector, 88-130. QulnnE Working Paper No. 6. Available at: http://quinne.eu

March, J. (1991). Exploration and Exploitation in Organizational Learning. Organization Science, 2(1), 71-87. 
Martín, F., Corchado, N., Fernández, L., Illéssy, M., \& Makó, C. (2018). Innovation, Job Quality and Employment Outcomes in the Agri-food Industry: Evidence from Hungary and Spain. In K. Jaehrling (ed), Virtuous circles between innovations, job quality and employment in Europe? Case study evidence from the manufacturing sector, private and public service sector, 131-177. QulnnE Working Paper No. 6. Available at: http://quinne.eu

Mathieu, C., Wright, S., Boethius, S., \& Green, A. (2020). Innovations on a shoestring: Consequences for job quality of public service innovations in health and social care, European Journal of Workplace Innovation, 5(2), 4-30.

Mathieu, C., Boethius, S., \& Martín, F. (2018). Innovation, Job Quality and Employment in Hospitals in Spain and Sweden. In K. Jaehrling (ed), Virtuous circles between innovations, job quality and employment in Europe? Case study evidence from the manufacturing sector, private and public service sector, 387 431. QulnnE Working Paper No. 6. Available at: http://quinne.eu

Mathieu, C. \& Warhurst, C. (2018). QulnnE Policy Recommendations. QulnnE Working Paper No.14. Available at: $\underline{\text { http://quinne.eu }}$

Mazzucato, M. \& Perez, C. (2015). Innovation as Growth Policy: The Challenge for Europe. In J. Fagerberg, S. Laestadius, \& B. Martin (eds), The Triple Challenge for Europe: Economic Development, Climate Change, and Governance Oxford: Oxford University Press, 229-264.

Muñoz-de-Bustillo, R., Grande, R., \& Fernández-Macías, E. (2016). Innovation and Job Quality. An Initial Exploration. QulnnE Working Paper No. 5. Available at: http://quinne.eu

Muñoz-de-Bustillo, R., Grande, R., \& Fernández-Macías, E. (2017). An approximation of job quality and innovation using the 3rd European Company Survey. QulnnE Working Paper No. 4. Available at: http://quinne.eu

OECD. (2005). Oslo Manual: Guidelines for Collecting and Interpreting Innovation Data, 3rd Edition. OECD Publications.

Perez, C. \& Martín, F. (2018). Digitalisation and Artificial Intelligence: The New Face of the Retail Banking Sector. Evidence from France and Spain. In K. Jaehrling (ed), Virtuous circles between innovations, job quality and employment in Europe? Case study evidence from the manufacturing sector, private and public service sector, 178-233. QulnnE Working Paper No. 6. Available at: http://quinne.eu

Zhou, H., Dekker, R., \& Kleinknecht, A. (2011). Flexible Labor and Innovation Performance: Evidence from Longitudinal Firm-level Data. Industrial and Corporate Change, 20(3), 941-968.

\section{About the authors}

Dr. Susanne Boethius, Department of Sociology, Lund University was Project Manager and researcher on the Horizon 2020 project QulnnE - Quality of Jobs and Innovation Generated Employment Outcomes. Together with Chris Mathieu she carried out the Swedish QulnnE case studies on hospitals/healthcare. Boethius is currently a researcher in the FORTE financed project "Call the police? A study of social networks' responses to domestic violence" and work-package leader in the Horizon 2020 project "DIHECO-Digital Healthcare ECOosvstem research and innovation capability building".

Chris Mathieu, Department of Sociology, Lund University was PI and project coordinator on the Horizon 2020 project QulnnE. He currently works in the Horizon 2020 projects Beyond 4.0 and DiHECO. The article "Innovations on a shoestring: Consequences for job quality of public service innovations in health and social care" with Wright, Boethius, and Green, based on QulnnE case studies was recently published the European Journal of Workplace Innovation, 2020 5(2). He is currently co-editing The Oxford Handbook of Job Quality (OUP). 